DOI: 10.20472/BMC.2018.008.017

\title{
PI-HSIA YEN
}

Yu Da University of Science and Technology, Taiwan

\section{FRAMEWORK BUILDING OF FINANCIAL PERFORMANCE INDEX FOR AIRPORTS- A CASE OF TAIWAN}

\begin{abstract}
:
This paper has constructed the representative financial performance evaluation indicators framework for different level airports (type A and B). This paper, by using airport's two main financial reports: "balance sheet" and "Income Statement" and accommodating with characteristics of revenue and expenditure of airports, divides financial evaluation into five elements of "solvency", "profitability", "return of investment", "assets turnover ratio" and "debts turnover ratio", 19 initial financial results evaluation indicators are achieved for proceeding the airports financial results evaluation. For the selection of indicators, this paper uses Grey Relation Analysis to examine the relationship between indicators. Those with high correlation are grouped and then a representative indicator is selected from among them. This method not only simplifies the complex work of evaluation, but can also manage such limitations as a dearth of information or unknown distribution types.
\end{abstract}

In application of the actual sample of A type airports' financial results evaluation, the numbers of evaluation indicator had been decreased from 19 to 6 and make the decreasing ratio $68.42 \%$. In application of the samples $B$ type airports' financial results evaluation, initial financial evaluation indicators had decreased from 19 to 5 representative ones. The evaluation indicators decreasing ratio is $73.68 \%$.

\section{Keywords:}

Airport, Financial Index Framework, Grey Relation Analysis

JEL Classification: G30 


\section{Introduction}

To build up a complete operation results evaluation indicators and help the industry discover operational problems and factors for elevating operation results are of real essence. Therefore, this paper will focus on six domestic airports which can be divided into two levels which are A: (Taoyuan, Taipei, Kaohsiung) and B: (Hualien, Tainan, Magong) for gathering the operational results as variables for evaluation. The paper will gather the financial evaluation indicator by taking two steps. The first will use [1] financial ratio classification method and accommodate with airport's financial reports and accounting specifics to obtain the initial financial evaluation indicator collection. The second step will be representative financial indicator structure build-ups. Due to lack of enough samples (A and B levels cover only three airports respectively.) and difficulty of data obtaining( financial reports' term last only one year), the grey relation analysis (GRA) will be used to select level A and B's representative financial indicators and thus build up the indicator structure.

\section{Literature Review}

Documents in relevance of using financial ratios to estimate evaluate and explain business operational results are plentiful. They have used financial ratio average to compare whether obvious difference exist between businesses of success and failure [2]. Decreasing 22 financial ratios to 5 is used to forecast the possibility of bankruptcy of business. They had decreased 48 financial ratios into 7 by using factor analysis method in order to build up distinguishing variables for evaluation of manufacturing industry's financial status [3]. They had utilized factor analysis method to select 4 financial ratios from 18 to analyze the financial characteristics of business after merger and acquisition [4]. Documents of using financial ratios to evaluate good and bad of transportation business operational results are plentiful. In the aspect of shipping industry, they uses the application and relating traits of main financial reports (Balance sheet, income statement, cash flow statement) as the initial financial ratio selection basis and divides the financial results into five sorts in total of 27 initial financial ratios and uses the grey relevance analysis method to choose 15 representative financial ratios to evaluate the 8 domestic sea transportation companies' operational results [5]. They uses operational cost, operational revenue, total assets, long term liabilities, reserve margin, sales return, shareholders' equity and return, and asset's return in total of 8 levels to proceed the evaluation of operational results of American Marine and Evergreen Marine Corp [6]. Taiwan Ltd. In the aspect of highway bus industry, they has first considered combining different type of indicator(transportation indicator, financial ratio, mix indicator) to evaluate road transportation industry's operational results [1]. Other relevant documents mostly add small numbers of accounting items into the evaluation indicator collections as assistance $[7,8,9,10,11,12]$. As for research documents specially focusing on airports financial evaluation are rare. They decompose financial evaluation into 5 which are flow ratio, financial leverage ratio, 
activity ratio, profit ratio and income/cost ratio to evaluate 24 main airports in Europe region [13]. Other relevant documents on airports focus mostly on researches of airports' productivity level of service and service quality $[14,15,16]$.

\section{Initial Financial Evaluation Indicators Set}

The paper will use the financial ratio classification methods of [1] and accommodate with airport's financial reports and accounting items characteristics to obtain initial financial evaluation indicators. However, due to the differences of governmental accounting and financial accounting in application of financial reports and accounting titles, the general business financial ratios will not be suitable to use for the government. Therefore, in use of financial reports, "balance report" will replace the "balance sheet, "income and expenditure report" will replace "income statement. Since airports did not edit, the cash flow statement will be omitted. In addition, in considering the characteristics of concentrating sources of airports' revenue, "leasing and right fees" are also included in the evaluation items. Concluding from the above, this paper will divide airport's finance into five elements of solvency, profitability, return of investment, assets turnover ratio and debts turnover ratio. The total of 19 initial financial results evaluation indicators' names and evaluation formula are shown as [Table 1].

\section{Applications}

According to the revised and passed "Airports Organization Regulations of Civil Aviation Bureau of Transportation Ministry" (2012), there are 18 domestic airports which are super airports (Taoyuan international airport), A type ports (Kaohsiung Airport and Taipei Airport), B type (Tainan Airport, Hualian Airport, Taidong Feng Nian Airport, and Peng Hu Ma Gong Airport), C type (Taichung Shui-Nan Airport, Jia-Yi Shui Shang Airport and Kimoy ShangYi Airport) and D type (Heng Chuan, Ping Dong, Chi Mei, Wang An, Lan Yu, Lu Dao, Ma Zu Nan Gan, Ma Zu Bei Gan) in total of five types. The super airport refers to the international airports. A-type airports are the important airlines' hubs as well as assisting ports for the international airports. B type airports belong to the frequent air transportation exchange hubs. C types are airways which frequencies are next to the $B$ type. $D$ types belong to the ports that are for temporary and emergency usage. This paper will target on the super, A and B types for the research purposes.

The data gathered in this paper are of the relevant documents of each airport issued during the year of 2012 such as Civil Aviation Fiscal Yearly Reports of 2012, Airports of Transportation Ministry Civil Aviation Entrepreneurial Operation and Management Planning Reports of 2013, Air transportation groups and accounting departments of airports and civil aviation bureau. When the data quantity are large enough and match 
the normal distribution deployment, most scholars will use mathematical statistical methods (factors analysis, cluster analysis, discriminate analysis and regression analysis) to tackle the relations among variable. However, when the data terms are not long enough and deployment types are unknown, this method will be inappropriate to use. Therefore, this paper, due to the actual situation of scarce factors and uncertain mathematical evidence distribution type, will select the representative indicators by using the grey relation analysis [17].

By using the grey relation analysis for grouping the indicators and accommodating relative total score method proposed by $[18,19]$ for selection of indicators, normalization values of evaluation indicators of $A$ and $B$ type airports' financial results are shown in [Table 2] and [Table 3]. Results of indicators group sorting and representative indicator for each group are shown in [Table 4] and [Table 5].

\section{Conclusions and Suggestions}

This paper, by using airport's two main financial reports: "balance sheet" and "Income Statement" and accommodating with characteristics of revenue and expenditure of airports, divides financial evaluation into five elements of "solvency", "profitability", "return of investment", "assets turnover ratio" and "debts turnover ratio", 19 initial financial results evaluation indicators are achieved for proceeding the airports financial results evaluation.

From Table 4, we conclude that this paper, in application of the actual sample of A type airports' financial results evaluation, the numbers of evaluation indicator had been decreased from 19 to 6 and make the decreasing ratio $68.42 \%$. In application of the samples B type airports' financial results evaluation, initial financial evaluation indicators had decreased from 19 to 5 representative ones [Table 5]. The evaluation indicators decreasing ratio is $73.68 \%$.

Due to the scarce number of research targets ( $A$ and $B$ types include only three airports respectively) and that limited by the research data term lasts only for one year (yearly financial data), this research applies the grey relation analysis for selecting the grouping of initial indicators of financial results evaluation. Highly relevant ones will be classified into one group and then most representative ones will again be selected from within for forming the representative indicators of financial evaluation structure. From Table 4 and 5, the indicators for A-type airports are not completely suitable for evaluating $B$ type airports. In proceeding airports financial evaluation and comparison, appropriate evaluation indicator structure should be designed for different type of airports. 
Table 1. Initial Financial Evaluation Index Set for Airports

\begin{tabular}{|c|c|c|c|}
\hline Classification & No. & Names of Indicator & Formula \\
\hline \multirow{2}{*}{ Solvency } & $\mathrm{FR}_{1}$ & Current Ratio & Current Assets/ Current Debts \\
\hline & $\mathrm{FR}_{2}$ & Debt Ratio & Total Assets/ Total Debts \\
\hline \multirow{4}{*}{ Profitability } & $\mathrm{FR}_{3}$ & Operation Ratio & $\begin{array}{l}\text { Operation Revenue/ Operation } \\
\text { Expenditure }\end{array}$ \\
\hline & $\mathrm{FR}_{4}$ & Sales Surplus Ratio & $\begin{array}{l}\text { Operation Surplus/ Operation } \\
\text { Revenue }\end{array}$ \\
\hline & $\mathrm{FR}_{5}$ & Surplus Ratio & Net Surplus/ Operation Revenue \\
\hline & $\mathrm{FR}_{6}$ & $\begin{array}{l}\text { Ratio of Leasing and right fees and } \\
\text { Operation Expenditure }\end{array}$ & $\begin{array}{l}\text { Leasing and right fees/ Operation } \\
\text { Expenditure }\end{array}$ \\
\hline \multirow{3}{*}{ Return of Investment } & $\mathrm{FR}_{7}$ & Current Assets Return Ratio & Net Surplus/ Current Assets \\
\hline & $\mathrm{FR}_{8}$ & Fixed Assets Return Ratio & Net surplus/ Fixed Assets \\
\hline & $\mathrm{FR}_{9}$ & Total Assets Return Ratio & Net Surplus/ Total Assets \\
\hline \multirow{4}{*}{ Assets Turnover Ratio } & $\mathrm{FR}_{10}$ & Current Assets Turnover Ratio & $\begin{array}{l}\text { Operation Revenue/ Current } \\
\text { Assets }\end{array}$ \\
\hline & $\mathrm{FR}_{11}$ & Fixed Assets Turnover Ratio & Operation Revenue/ Fixed Assets \\
\hline & $\mathrm{FR}_{12}$ & Total Assets Turnover Ratio & Operation Revenue/ Total Assets \\
\hline & $\mathrm{FR}_{13}$ & $\begin{array}{l}\text { Ratio of Leasing and right fees and } \\
\text { Current Assets }\end{array}$ & $\begin{array}{l}\text { Leasing and right fees/ Current } \\
\text { Assets }\end{array}$ \\
\hline \multirow{2}{*}{ Assets Turnover Ratio } & $\mathrm{FR}_{14}$ & $\begin{array}{l}\text { Ratio of Leasing and right fees and } \\
\text { Fixed Assets }\end{array}$ & $\begin{array}{l}\text { Leasing and right fees/ Fixed } \\
\text { Assets }\end{array}$ \\
\hline & $\mathrm{FR}_{15}$ & $\begin{array}{l}\text { Ratio of Leasing and right fees and } \\
\text { Total Assets }\end{array}$ & $\begin{array}{l}\text { Leasing and right fees/ Total } \\
\text { Assets }\end{array}$ \\
\hline \multirow{4}{*}{ Debts Turnover Ratio } & $\mathrm{FR}_{16}$ & Current Debts Turnover Ratio & $\begin{array}{lll}\text { Operation Revenue/ Current } \\
\text { Debts }\end{array}$ \\
\hline & $\mathrm{FR}_{17}$ & Total Debts Turnover Ratio & Operation Revenue/ Total Debts \\
\hline & $\mathrm{FR}_{18}$ & $\begin{array}{l}\text { Ratio of Leasing and right fees and } \\
\text { Current Debts }\end{array}$ & $\begin{array}{l}\text { Ratio of Leasing and right fees / } \\
\text { Current Debts }\end{array}$ \\
\hline & $\mathrm{FR}_{19}$ & $\begin{array}{l}\text { Ratio of Leasing and right fees and } \\
\text { Total Debts }\end{array}$ & $\begin{array}{l}\text { Ratio of Leasing and right fees/ } \\
\text { Total Debts }\end{array}$ \\
\hline
\end{tabular}


Table 2. Normalization Value of Financial Performance Evaluation Index for Type A

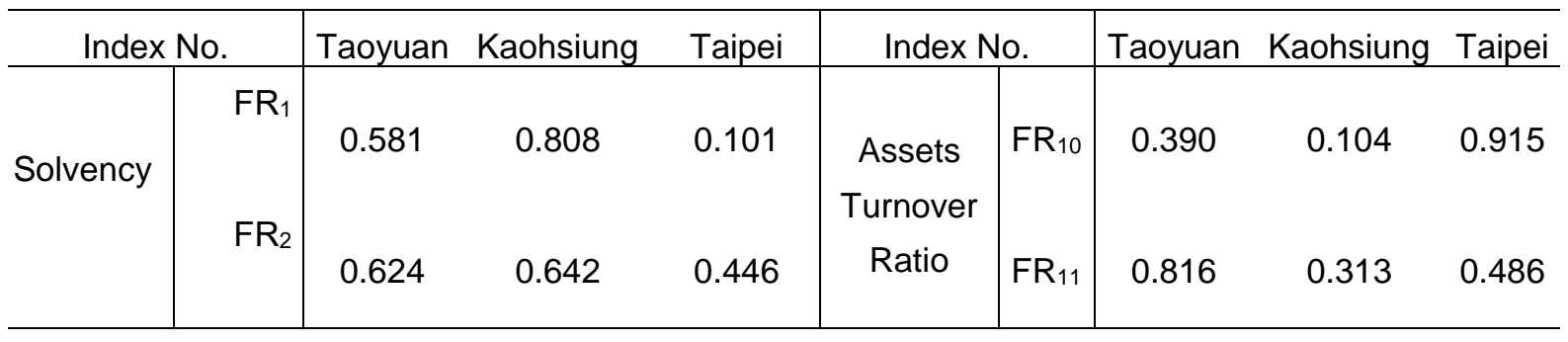

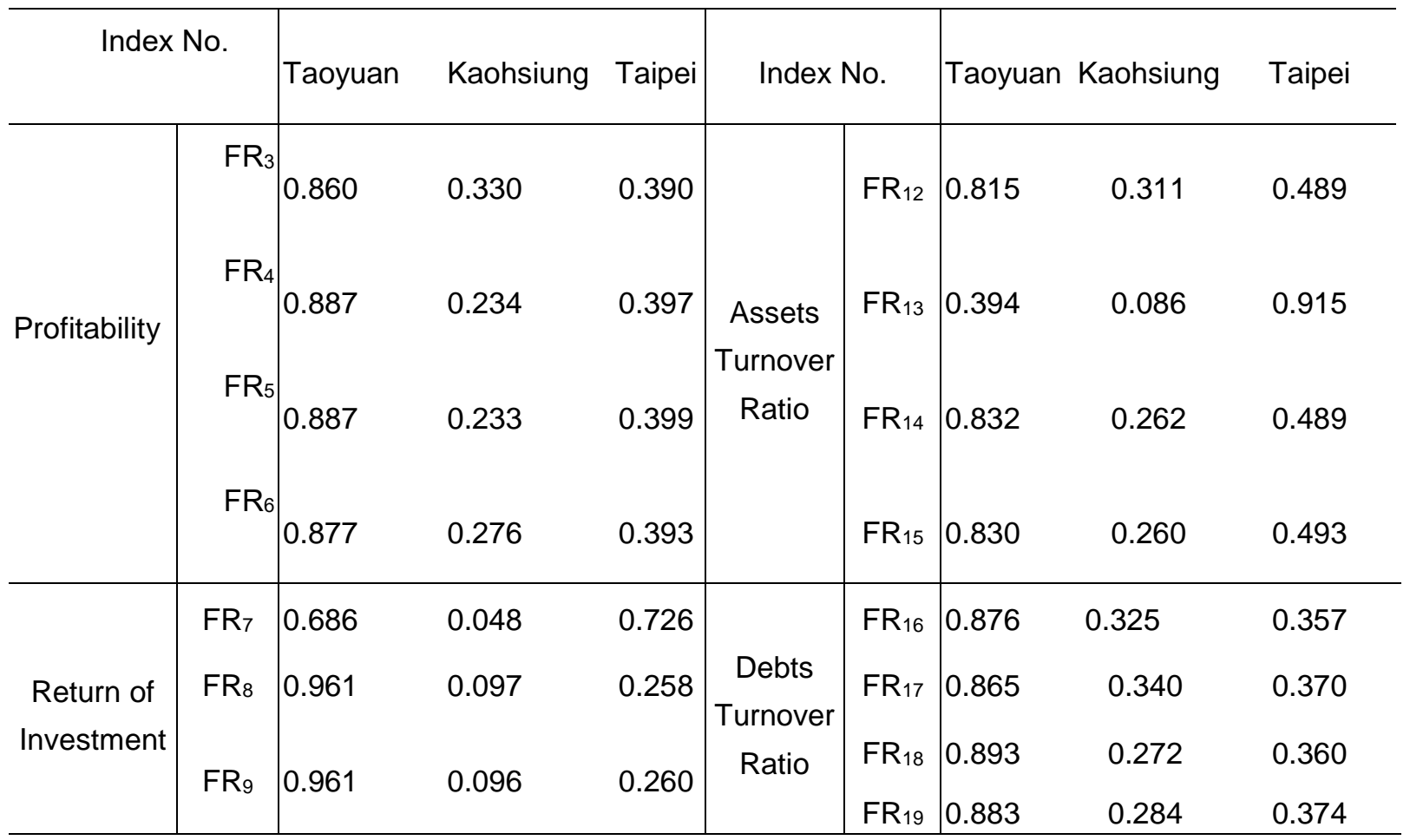


Table 3. Normalization Value of Financial Performance Evaluation Index for Type B

\begin{tabular}{|c|c|c|c|c|c|c|c|c|c|}
\hline \multicolumn{2}{|c|}{ Index No. } & Tainan & Hualien & Magong & \multicolumn{2}{|c|}{ Index No. } & Tainan & Hualien & Magong \\
\hline \multirow[t]{2}{*}{ Solvency } & $\mathrm{FR}_{1}$ & 0.412 & 0.302 & 0.859 & \multirow{6}{*}{$\begin{array}{c}\text { Assets } \\
\text { Turnover } \\
\text { Ratio }\end{array}$} & $\mathrm{FR}_{10}$ & 0.495 & 0.851 & 0.176 \\
\hline & $\mathrm{FR}_{2}$ & 0.226 & 0.494 & 0.839 & & $\mathrm{FR}_{11}$ & 0.900 & 0.408 & 0.151 \\
\hline \multirow{4}{*}{ Profitability } & $\mathrm{FR}_{3}$ & 0.806 & 0.529 & 0.265 & & $\mathrm{FR}_{12}$ & 0.862 & 0.479 & 0.165 \\
\hline & $\mathrm{FR}_{4}$ & -0.020 & -0.262 & -0.965 & & $\mathrm{FR}_{13}$ & 0.040 & 0.986 & 0.163 \\
\hline & \multirow{2}{*}{$\mathrm{FR}_{6}$} & -0.019 & -0.262 & -0.965 & & $\mathrm{FR}_{14}$ & 0.145 & 0.949 & 0.281 \\
\hline & & 0.097 & 0.924 & 0.371 & & $\mathrm{FR}_{15}$ & 0.119 & 0.957 & 0.265 \\
\hline \multirow{4}{*}{$\begin{array}{l}\text { Return of } \\
\text { Investment }\end{array}$} & $\mathrm{FR}_{7}$ & -0.033 & -0.795 & -0.606 & \multirow{4}{*}{$\begin{array}{c}\text { Debts } \\
\text { Turnover } \\
\text { Ratio }\end{array}$} & $\mathrm{FR}_{16}$ & 0.565 & 0.712 & 0.418 \\
\hline & $\mathrm{FR}_{8}$ & -0.092 & -0.589 & -0.803 & & $\mathrm{FR}_{17}$ & 0.580 & 0.703 & 0.412 \\
\hline & $\mathrm{FB}_{\mathrm{g}}$ & -0.079 & -0616 & -0784 & & $\mathrm{FR}_{18}$ & 0.050 & 0.903 & 0.426 \\
\hline & & & & & & $\mathrm{FR}_{19}$ & 0.052 & 0.904 & 0.425 \\
\hline
\end{tabular}


Table 4. Financial Performance Evaluation Index Groups for Type A

\begin{tabular}{|c|c|c|}
\hline $\begin{array}{l}\text { Order of } \\
\text { Group }\end{array}$ & Representative Indicator for each Group & Indicators within each Groups \\
\hline FR-I & $\mathrm{FR}_{1}$ (Current Ratio) & $\mathrm{FR}_{1}$ \\
\hline FR-II & $\mathrm{FR}_{2}$ (Debts Ratio) & $\mathrm{FR}_{2}$ \\
\hline FR-III & $\begin{array}{l}\text { FR }_{6} \text { (Ratio of Leasing and right fees and Operation } \\
\text { Expenditure ) }\end{array}$ & $\begin{array}{l}F R_{3}, F R_{4} 、 F R_{5}, F R_{6} 、 F R_{11} \\
F R_{12} 、 F R_{14} 、 F R_{15} 、 F R_{16} \\
F R_{17}, F R_{18}, F R_{19}\end{array}$ \\
\hline FR-IV & $\mathrm{FR}_{7}$ (Current Assets Return Ratio) & $\mathrm{FR}_{7}$ \\
\hline FR-V & $\mathrm{FR}_{9}$ (Total Assets Return Ratio) & FR8, $\mathrm{FR}_{9}$ \\
\hline FR-VI & $\mathrm{FR}_{13}$ (Ratio of Leasing and right fees and Current Assets) & $\mathrm{FR}_{10}, \mathrm{FR}_{13}$ \\
\hline
\end{tabular}

Table 5. Financial Performance Evaluation Index Groups for Type B

\begin{tabular}{|c|c|c|}
\hline $\begin{array}{l}\text { Order of } \\
\text { Group }\end{array}$ & Representative Indicator for each Group & Indicators within each Groups \\
\hline FR-I & $\mathrm{FR}_{2}$ (Debts Ratio) & $F_{1} 、 F R_{2}$ \\
\hline FR-II & FR $_{12}$ (Total Assets Turnover Ratio) & $\mathrm{FR}_{3}, \mathrm{FR}_{11}, \mathrm{FR}_{12}$ \\
\hline FR-III & FR8 (Fixed Assets Return Ratio) & $\mathrm{FR}_{4} 、 \mathrm{FR}_{5} 、 \mathrm{FR}_{7} 、 \mathrm{FR}_{8}, \mathrm{FR}_{9}$ \\
\hline FR-IV & $\mathrm{FR}_{15}$ (Ratio of Leasing and right fees and Total Assets) & $\begin{array}{l}F R_{6} 、 F R_{13} 、 F R_{14} 、 F R_{15} 、 F R_{18} 、 \\
F R_{19}\end{array}$ \\
\hline FR-V & $\mathrm{FR}_{16}$ (Current Debts Turnover Ratio) & $F R_{10}, F R_{16}, F R_{17}$ \\
\hline
\end{tabular}


Table 6. Representative indicator and index within-group for Type A and B

\begin{tabular}{|c|c|c|c|c|c|}
\hline \multicolumn{3}{|c|}{ Type A } & \multicolumn{3}{|c|}{ Type B } \\
\hline Order & Representative indicator & $\begin{array}{l}\text { Index } \\
\text { within-group }\end{array}$ & Order & Representative indicator & $\begin{array}{c}\text { Index } \\
\text { within-group }\end{array}$ \\
\hline FR-I & $\mathrm{FR}_{1}$ (current ratio) & $\mathrm{FR}_{1}$ & FR-I & $\mathrm{FR}_{2}$ (debts ratio) & $\mathrm{FR}_{1} \cdot \mathrm{FR}_{2}$ \\
\hline FR-II & $\mathrm{FR}_{2}$ (debts ratio) & $\mathrm{FR}_{2}$ & FR-II & $\begin{array}{l}\mathrm{FR}_{12} \text { (total assets turnover } \\
\text { ratio) }\end{array}$ & $\begin{array}{l}F R_{3} 、 F R_{11} 、 \\
F R_{12}\end{array}$ \\
\hline FR-III & $\begin{array}{l}\mathrm{FR}_{6} \text { (ratio of leasing and } \\
\text { right fees and operation } \\
\text { expenditure) }\end{array}$ & $\begin{array}{l}F R_{3} 、 F_{4} 、 F_{5} \\
F R_{6} 、 F_{11} \\
F R_{12} 、 F_{14} 、 \\
F R_{15} 、 F_{16} 、 \\
F R_{17} 、 F_{18} \\
F R_{19}\end{array}$ & FR-III & $\begin{array}{l}\text { FR8 (fixed assets return } \\
\text { ratio) }\end{array}$ & $\begin{array}{l}F R_{4} \cdot F \cdot \\
F R_{7} \cdot F R_{8} \cdot F R_{9}\end{array}$ \\
\hline FR-IV & $\begin{array}{l}\mathrm{FR}_{7} \text { (Current Assets } \\
\text { Return Ratio) }\end{array}$ & $\mathrm{FR}_{7}$ & \multirow[t]{2}{*}{ FR-IV } & \multirow{2}{*}{$\begin{array}{l}\mathrm{FR}_{15} \text { (ratio of leasing } \\
\text { and right fees and total } \\
\text { assets) }\end{array}$} & \multirow{2}{*}{$\begin{array}{l}F R_{6} 、 F_{13} 、 \\
F R_{14} \cdot F_{15} 、 \\
F R_{18} 、 F R_{19}\end{array}$} \\
\hline FR-V & $\begin{array}{l}\text { FRg(Total Assets } \\
\text { Return Ratio) }\end{array}$ & $\mathrm{FR}_{8} \cdot \mathrm{FR}_{9}$ & & & \\
\hline FR-VI & $\begin{array}{l}\mathrm{FR}_{13} \text { (Ratio of Leasing } \\
\text { and right fees and } \\
\text { Current Assets) }\end{array}$ & $F R_{10} \cdot F R_{13}$ & FR-V & $\begin{array}{l}\mathrm{FR}_{16} \text { (current debts } \\
\text { turnover ratio) }\end{array}$ & $\begin{array}{l}\mathrm{FR}_{10} \cdot \mathrm{FR}_{16} 、 \\
\mathrm{FR}_{17}\end{array}$ \\
\hline
\end{tabular}




\section{References}

Feng, C. M. \& Wang, R. T. 2001. Considering the Financial Ratios on the Performance Evaluation for Highway Bus Industry, Transport Reviews, 21 (4), 449-467.

Altman, E. I. 1968. Financial Ratios, Discriminate Analysis and the Prediction of Corporate Bankruptcy, Journal of Finance, 23 (4), 589-609.

Pinches, G. E. \& Mingo, K. A. 1973. The Stability of Financial Patterns in Industrial Organizations, Journal of Finance, 28 (1), 389-396.

Stevens, D. L. 1973. Financial Characteristics of Merged Firm: A Multivariate Analysis, Journal of Financial and Quantitative Analysis, 8 (1), 257-278.

Wang, R. T. and Feng, C. M. 2000, Financial Performance Evaluation for Domestic Listed Shipping Companies, Traffic and Transportation, 19, 1-13.

Seok-Min Lim. 1996. Round-the-world Service: The Rise of Evergreen and the Fall of U.S. Lines, Maritime Policy and Management, 23 (2), 119-144.

Allen, W. G. \& Dicease, F. 1976. Transit Service Evaluation: Preliminary Identification of Variables Characterizing Level of Service, Transportation Research Record, 606, 41-47.

Chang, K.P. \& Kao, P. H. 1992. Relative Efficiency of Public Versus Private Municipal Bus Firm: An Application of Date Envelopment Analysis, The Journal of Productivity Analysis, 3, 67-84.

Chu, X. \& Fielding, G. J. 1992. Measuring Transit Performance Using Date Envelopment Analysis, Transportation Planning and Technology, 4, 97-103.

Fielding, G. J., Babitsky, T. T. \& Brenner, M. E. 1985. Performance Evaluation for Bus Transit, Transportation Research, 19A (1), 73-82.

Fielding, G. J. \& Anderson, S. C. 1984. Application to Section 15 Data, Transportation Research Record, 947, 1-7.

Tanaboriboon, Y., Quium, A.S.M.A. \& Changsingha, C. 1993, Performance Indicator Analysis: A Management Tool for the Improvement of Bus Transit Operation in Bangkok, Journal of Advanced Transportation, 27 (2), 207-223.

Doganis, R. \& Graham, A. 1987. Airport Management: The Role of Performance Indicators, Transport Studies Group, Polytechnic of Central London, London.

Gillen, D. \& Lall, A. 1997. Developing measures of airport productivity and performance: an application of data environment analysis, Transportation Research Part-E, 33 (4), 261-273.

Hooper, P.G. \& Hensher, D. A. 1997. Measuring Total Factor Productivity of Airports - An Index Number Approach, Transportation Research-E, 33 (4), 249-259.

Juan Carlos Martin \& Cocepcion Roman. 2001. An Application of DEA to measure the efficiency of Spanish airports prior to privatization, Journal of Air Transportation Management, 7, 149-157.

Deng, J. L. 1982 Control Problems of Grey Systems, Systems and Control Letters, 5, 288-294.

Wang, R. T. 2001. Framework Building and Application of the Performance Evaluation in Transport Industries- Cases of Highway Buses and Domestic Airlines, Dissertation Thesis, National Chiao Tung University, Taiwan, ROC.

Mathisen, T. A.; Jorgensen, F.; Solvoll, G. 2014, Marginal costs pricing of airport operations in Norway, Research in Transportation Economics, 45, 49-56. 